\title{
The Research on the Predicament of Further Promoting the Reform of Real Estate Tax
}

\author{
Luxi Lu \\ Southwest Minzu University, Chengdu, China \\ Email:215219383@qq.com
}

How to cite this paper: Lu, L. X. (2020). The Research on the Predicament of Further Promoting the Reform of Real Estate Tax. Current Urban Studies, 8, 417-427. https://doi.org/10.4236/cus.2020.83023

Received: August 24, 2020

Accepted: August 31, 2020

Published: September 3, 2020

Copyright (c) 2020 by author(s) and Scientific Research Publishing Inc. This work is licensed under the Creative Commons Attribution International License (CC BY 4.0).

http://creativecommons.org/licenses/by/4.0/ (c) (i) Open Access

\begin{abstract}
The price of real estate has been rising in recent years in our country, and the proportion of the consumption of urban households in housing investment gradually increases in the proportion of disposable income, which has affected the consumption of the urban residents. And at the same time, the real estate markets gradually become the markets of investment and hype. The high housing prices also contributed to the social gap between the rich and the poor. Therefore, the real estate tax reform is particularly important. However, since 2010, our country has put forward the reform of property tax, but the effect of the property tax reform practice is limited. So this article will discuss the existing problems in the process of further promoting the reform of real estate tax in China, such as the legislation of the reform of real estate tax, the coordination and consideration of the reform of real estate tax under the huge differences in housing prices, and the real estate information registration system in order to comb through to the existing problems, find the barriers and difficulties in further promoting the reform of the property tax, which has positive significance to further promoting the reform of the property tax.
\end{abstract}

\section{Keywords}

Real Estate Tax Reform, Legislative Dilemma, Limited System

\section{Introduction}

It has been nine years since China put forward the reform of real estate tax and carried out the pilot practice. However, up to now, the pilot work has not been extended to the whole country. And the legislation of real estate tax is still in the process of implementation, and China has not yet levied the real estate tax. The reform of property tax involves many aspects, and the difficulties encountered 
are obvious. Therefore, it is the only way to solve the existing problems and promote the reform of real estate tax to summarize and discuss the barriers and difficulties in the process of real estate tax reform.

\section{The Current Situation of Reform of the Real Estate Tax System}

\subsection{The Policy Status of Reform of the Real Estate Tax System}

"The Provisional Regulations of the People's Republic of China on Real Estate Tax" was promulgated and implemented by the State Council as early as September 15, 1986, and was amended on January 8, 2011 in accordance with "The Decision of the State Council on The Repeal and Amendment of Some Administrative Regulations" No. 588 by The State Council Decree. The reform of real estate tax was first proposed in China on May 31, 2010, when the Chinese government website issued "The Notice of The State Council's Approval and Transfer of the Development and Reform Commission's Opinions on the Key Work of Deepening the Economic Restructuring in 2010". And the article four of the notice points out that the reform of fiscal and tax systems should be deepened and the reform of real estate tax gradually promoted. After the announcement, Shanghai and Chongqing began to collect the real estate tax as a pilot on January 28 , 2011. In 2012, the State Council pointed out that we should steadily push forward the pilot reform of real estate tax. And in 2013, the third Plenary Session of the 18th CPC Central Committee proposed to accelerate the legislation of real estate tax and timely promote the reform". Besides, Premier Li Keqiang has delivered a government work report at the opening of the second Session of the 13th National People's Congress on March 5, 2019. The report called for improving the local tax system and steadily advancing the legislation of real estate tax.

\subsection{The Present Situation of the Reform of Real Estate Tax System}

On January 28, 2011, Shanghai and Chongqing took the lead in taxing individual housing as a pilot of real estate tax reform. There are similarities and differences in the provisional measures implemented by Shanghai and Chongqing. One of the same point is that the tax object is focused on the newly purchased housing; Second, tax rates are levied according to the transaction price in order that the differential tax rates are set for the different proportion of the average selling price of new commercial housing in the pilot year. Third, setting the relatively relaxed tax exemption policy to reduce the infringement of residents' basic housing demand. One of the difference is reflected in the different tax coverage. Shanghai pilot covers the whole city, but Chongqing pilot covers the main nine urban areas; Second, in terms of the tax target, although Shanghai's pilot project focuses on newly purchased housing, it takes the total number of family housing and the number of family population into consideration, and takes the number of per capital area as the setting scope of exemption and exemption. However, 
Chongqing's pilot project only applies to newly purchased housing. Third, Chongqing is piloting high-end housing, while Shanghai is piloting incremental housing. The author plotted and analyzed the real estate tax revenue of Shanghai and Chongqing from 2009 to 2019 (Picture 1), which showed that the real estate tax revenue of Chongqing increased steadily in the past 10 years, and the real estate tax revenue of Shanghai also showed a steady rise from 2009 to 2014.

In terms of the proportion of real estate tax to the total tax revenue of the region (Picture 2), the proportion of real estate tax to the total tax revenue of the region in 2011 was $2.32 \%$, and there is an increase of $0.02 \%$ compared with that of 2010. In 2011, Chongqing real estate tax accounted for $2.37 \%$ of the total tax revenue in this region, which was $0.11 \%$ higher than that in 2010 . At the same time, it can be seen from Picture 2 that on the eve of the real estate tax reform in Shanghai and Chongqing, in 2010, the proportion of real estate tax in the two cities both showed a significant drop, exceeding $0.4 \%$ as a whole. The promotion of property tax reform has an impact on the real estate market, but it does not always present a positive impact as officially expected.

Thus, we can see that as a property tax pilot reform in 2011, there was not dramatically increased in 2010 on both Chongqing and Shanghai, and the increase in the property tax is similar to the property tax reform in 2009 and 2010 two years before. And the effect of two pilots is not obvious that through to expand tax sources, increase tax revenues by the real estate tax reform.

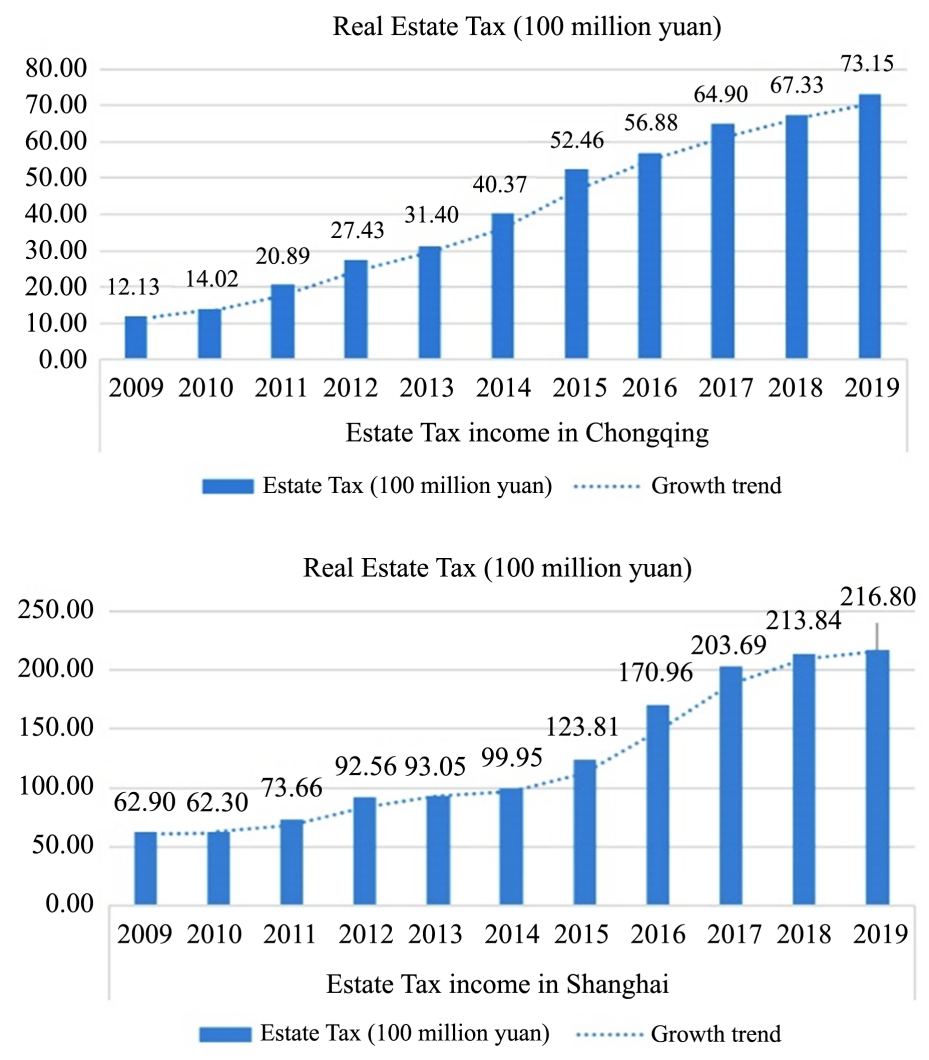

Picture 1. By author. Data from the national statistical yearbook 2009-2019. 
Percentage of real estate tax

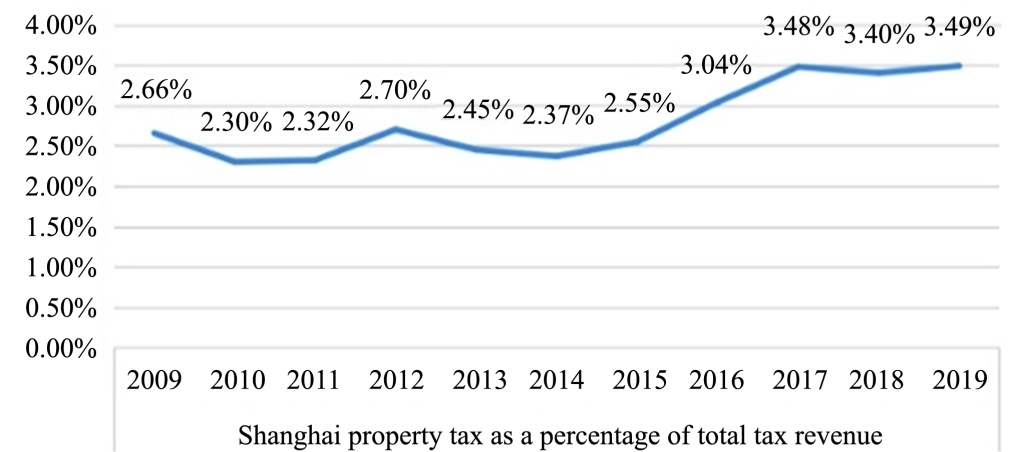

- Percentage of real estate tax

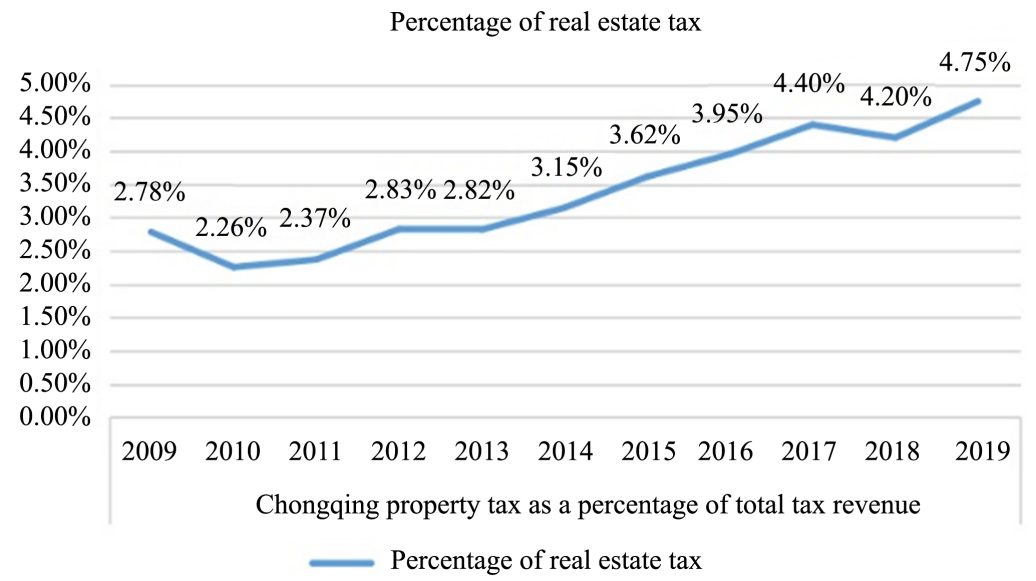

Picture 2. By author. Data from the national statistical yearbook 2009-2019.

\section{Further Push Forward the Legislation Dilemma of the Real Estate Tax Reform}

\subsection{The Dilemma of Real Estate Tax Reform Legislation in China's Legislative System}

In China as early as 2013 on the third plenary session of the eighteenth had been clearly put forward that speeding up the reform of real estate tax legislation and timely boost the reform. According to the sixth paragraph of article 8 of "The Legislation Law of the People's Republic of China regulations", the using, sorting and establishing of the tax, the direct determination of tax and the specific tax implement supervision and inspection of land tax management and related land tax basic policy laws and regulations system and so on all can directly in accordance with the law formulated in the country. However, the development of disposable economic is unbalanced in China, and the fiscal revenue of disposable economic and real estate market are different from each other around the city and province. So in reform of property tax laws and regulations in our country, it is difficult for the property tax, tax rate of object of various aspects, such as reduction factors, rules regulations setting to form a unified basic (Zhang, 2015). If we want to have the full consideration and comprehensive analysis of the spe- 
cific situation of the different provinces and the city's real estate tax, such as the situation of real estate and added-value tax market, the situation of disposable income of the local economy and the situation of local residents per capita disposable income of each factors, we need unity under the support of the National People's Congress formulating real estate tax law practical premise, to study and formulate detailed rules, laws and regulations on property tax by the central and the local people's congress, according to the specific condition of the local, thus, laws and regulations in China's real estate tax reform implementation can be more in line with the local reality, and it can gradually increase the fiscal revenue of local people's governments, promote the construction of central and local public service systems, and increase the well-being of local residents per capita (Jiang, 2017). In addition, due to the same city and the province has different cities, and the county market of real estate tax there may be a larger difference, so in the process of drafting and formulating laws and regulations of the real estate tax, we need to continue to go through the proposing, deliberation and voting of the real estate tax law draft until the People's Congress has adopted and officially promulgated this series of procedures. So in the future, our country also need go through long-term practice and discussion to promote the reform of real estate tax legislation.

\subsection{The Current Temporary Regulations on Real Estate Tax and the Lag of Local Regulations}

“The Interim Regulations of the People's Republic of China on Real Estate Tax" was promulgated by the State Council on September 15, 1986, taking effect on October 1, 1986, and was amended on January 8, 2011 in accordance with "The Decision of the State Council on The Repeal and Amendment of Some Administrative Regulations" No. 588 by the State Council Decree. The revised content includes that makes "The Interim Regulations of the People's Republic of China on the Administration of Tax Collection" in article 8 of the "Provisional Regulations of the People's Republic of China on Property Tax" changed to "Law of the People's Republic of China on the Administration of Tax Collection", therefore, in addition to modify the content of the entry, the present real estate tax collection objects and imposing tax rate as stipulated enacted in 1986 is still the content, namely the scope of the property tax, in view of the business housing tax towns and industrial and mining areas, only non-operational for urban residential and rural residential did not require. If the tax rate is calculated based on the residual value of the property, the tax rate shall be $1.2 \%$; In addition, only Shanghai and Chongqing have piloted the provisional regulations on local real estate tax, further setting the local property tax base and tax rate, but the tax is only levied on high-end residential buildings and newly purchased residential buildings.

Since promulgated the interim regulations on real estate tax, which already has been twenty-four years, after the housing reform in 1998, the current real 
estate market has developed rapidly in our country, and the original one has not fully adjusted and ruled the booming development trend of the current real estate market. And the corresponding the interim regulations on real estate tax should be combined with China's national conditions and the characteristics of the development of the market to revise, to meet the needs of the current market.

\section{The Predicament of Promoting the Real Estate Tax Reform under the Land Finance System}

\subsection{The Constitution Connotation of Total Investment of Construction Project}

The total cost of each construction project from the planning stage to the final completion of construction and later put into operation and use is called the total investment of the construction project in a series of process. The total investment of construction project mainly includes two parts: the investment in fixed assets and current assets investment. And the fixed assets investment contains six parts, and they are equipments and workers, equipment purchase cost, construction and installation engineering cost, other cost of engineering construction, the reserve funds, construction loan interest and fixed assets investment adjustment tax. Among them, other expenses for project construction include the fee of the land using, other expenses related to project construction and other expenses related to future production and operation of the enterprise. Therefore, when residential buildings, commercial buildings and other construction projects are sold, the price level is affected by the total investment level of the construction project.

\subsection{The Influence of Land Finance System on Promoting Real Estate Tax Reform in China}

The selling price of the construction project mentioned above is affected by the total investment amount of the construction project, among which the land use fee occupies a large proportion in the total investment amount of the construction project. The fee of land using, or gold of land sell one's own things, refers to the fee the receiver of the land giving to the government according to the rules when the land administration departments of governments at all levels will grant the right to the use of the land to the land users, which refers to the total transaction of land, or when the land users who have acquired the right to the use of the land through administrative allocation shall, in accordance with the relevant provisions, making up the land transfer price by transferring, leasing, mortgaging and making up the value of the right to the use of the land From 2009 to 2018 , the income of our country's local government land transferring is rising. In 2018, the local government land transferring income is 6.5096 trillion yuan (Bureau of Statistics of the People's Republic of China, 2019), which is four times that of the 2009 land transfer revenue of 1.591 trillion yuan (Bureau of Statistics 
of the People's Republic of China, 2010). The author analyzed the land supply and the land income from 2009 to 2018, and got the conclusion of units per acre of land transfer price is rising (Picture 3). As a result of the increase in the price of land transferring, resulting in a large increase in the total investment in construction projects, thereby the price of housing is increasing. It is precisely because of the rise of housing prices and the strong development of the real estate industry that the demand for land is gradually increased, which further promotes the continuous rise of land transferring fees and becomes an important income of local governments, and also promotes the formation of the "land finance" model. Since 2009, China's land transferring revenue has been an important part of local government revenue, and the proportion of land transferring revenue to local general public budget revenue has been higher than $20 \%$. In the past 10 years, among that, the six-year land transferring revenue has accounted for more than $30 \%$ of local general public budget revenue (Picture 4 ).

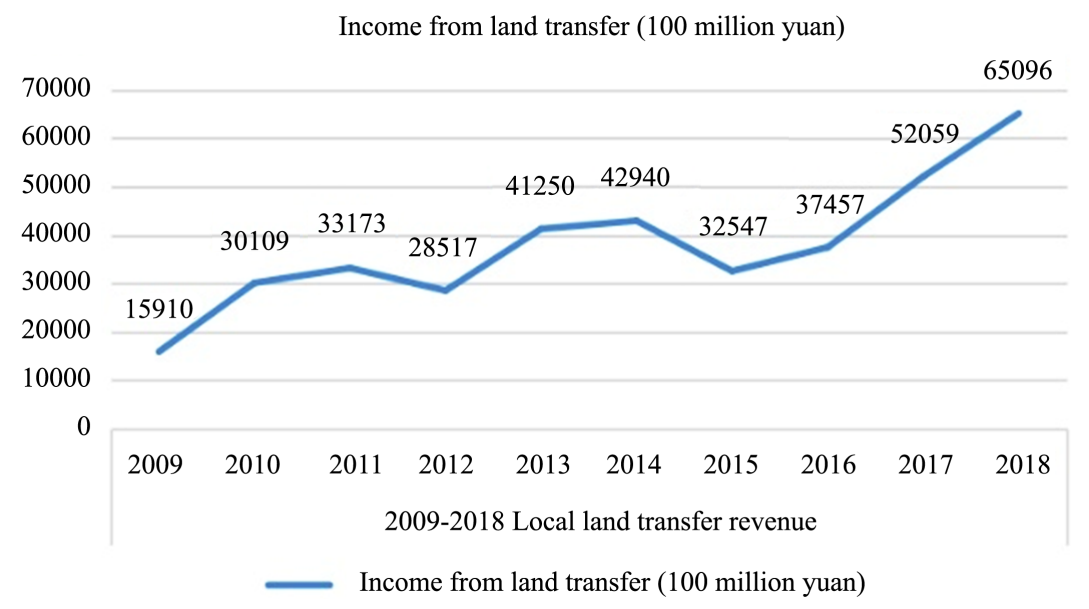

Picture 3. By author. Data from the national statistical yearbook 2009-2018 ministry of finance website.

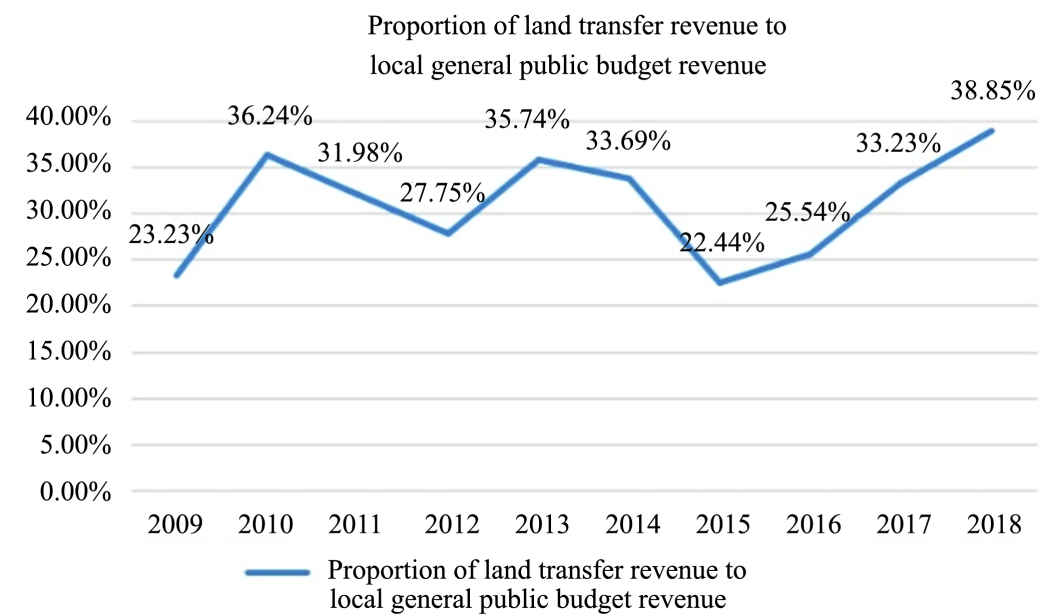

Picture 4. By author. Data from the national statistical yearbook 2009-2018 ministry of finance website. 
The promoting of the reform of the property tax can realize the prices controlling and the adjustment of the gap between rich and poor, but due to the increasing prices of land and land transfer income is a function of two-way to stimulate demand, it can increase the local fiscal revenue in the short term, and at the same time it can promote real estate related building materials and equipment markets, such as the development of the market, and solve the employment problem of some migrant workers. So the central government consider the problem of real estate tax reform from the eyesight of global. And it is bound to weigh the local economic development and employment, etc., and the local government for the sake of local interest may be delayed in the reform of the property tax. The land finance issue poses a relatively big challenge to the reform of property tax of self-owned housing (Lan, 2013).

\section{The Limitations of the Real Estate Property Right Information Supporting System}

\subsection{The Lags of the Registration of Real Estate Property Rights and Usage Information}

China's real estate property right information registration is based on the "The Provisional Regulations on Realty Registration", among that the article 20 of which stipulates that the realty registration organ shall complete the registration procedures of realty within 30 working days from the date of accepting the registration application, unless otherwise provided by law. But due to many types of real estate products in our country's real estate market, there are existing home transactions, which also have period room trading, and most of the period room in the basement of the roof building. After the completion of real estate, developers can apply for booking licence for the premises to open to book them. And these period room can be registered their real estate property right information only after the construction completion, and completion acceptance after the consign being used (Hou, 2017). The scale and duration of construction projects are different, and the registration time of property rights information is different after the property transaction. After the completion of real estate transaction and the registration of real estate information, the delivery time of real estate certificate still varies. Even after some real estate transaction, the real estate certificate is still not handled successfully for more than ten years. In spite of this, a lot of real estate that not obtained relevant certificate is still trading, and some moreover also changed owners several times. Through several after selling, the "owner" of handing property and the "owner" of registration of the real estate property right is not unified. And the universal existence of small property right, and real estate information to carry out the real difficulties, which makes it harder to further promote the reform of property tax.

According to statistics on the official website of the Ministry of Agriculture and Natural Resources, China has basically realized the nationwide networking of the real estate registration information management system, and has set up 
3,001 service halls of the rural real estate using right registration management system in 335 provincial capital cities and 853 counties. But currently a few natural persons jointly build old house property registration information for house-site in the countryside, and natural person build the rural collective land property rights of small property right registration information. And rural Laos and other big cities without an old residential property right register information according to the actual situation. As a result of the rural property right registration and management status, property right and property right share factors leading to the implementation of the property right registration information more difficult, and these are not clear the status quo of rural property right registration for perfect rural property right registration information, rural property registration and management to promote rural reform and development of the real estate tax system has added a new dilemma.

\subsection{The Dilemma of Tax on Property Information in Different Places}

The existing real estate information system still has some shortcomings. One is that the property information in China adopts the principle of territorial management. In information registration, information should be registered by individuals rather than families. In the case of a joint possession, each person's share shall be registered, but in the case of a single possession, only that person's information shall be registered. This situation leads to the following situation, that is, if different family members buy houses in different cities, and the right person is a different member of the same family. This phenomenon of cross-city buying leads to the difficulty in the statistics of the total real estate information held by families. Secondly, different provinces and cities have different local policies and regulations, different tax bases and tax rates, and different purchase restriction policies. Cross-city purchase behavior makes it difficult to formulate the plan of the area subject to real estate tax and the policy of setting the number of sets. The levied objects in Shanghai are new houses purchased by residents of the city, belonging to the second and above houses and new houses purchased by non-residents of the city. The tax rate is tentatively set at $0.6 \%$. In Chongqing, the tax rate is $0.5 \%-1.2 \%$ for single-family villas, high-end apartments, and second homes purchased by people without a working account or investment. There are 23 provinces, 5 autonomous regions and 4 municipalities directly under the central government in China. The population distribution and economic development are extremely unbalanced. The demand for housing in cities is greater than that in rural areas, and the demand for housing in eastern coastal areas is greater than that in western plateau areas. Therefore, it is difficult for all provinces and cities to promote the reform of property tax. Third, the phenomenon of cross-city purchase, or even the formation of the "property speculation" mechanism, the real estate market to restrict speculation to form a barrier. 
For example, before the introduction of the 2016 fixed term purchase policy, the average price of real estate in Chengdu in 2016 was 8591 yuan $/ \mathrm{m}^{2}$, which was not restricted at that time. Individuals with or without Chengdu household registration can purchase their own houses or investment properties on demand. In 2017, the average price of real estate in Chengdu rose to $12,034 \mathrm{yuan} / \mathrm{m}^{2}$ (China Real Estate Association, 2018), and in 2018 it was 13,173 yuan $/ \mathrm{m}^{2}$ (China Real Estate Association, 2019), Although the purchase restriction policies have been issued one after another, the rapid rise and volatility of housing prices make the government have to promote the improvement and implementation of the policy year by year according to the current situation of the market. However, the promotion of real estate tax reform and the formulation of tax base and tax rate have universality and timeliness. Therefore, the rapid rise of house prices and the sharp fluctuation of real estate market caused by the "real estate speculation" mechanism make it difficult for the real estate tax reform to coordinate the nationwide promotion.

\section{Conclusion}

China's property tax reform and property tax legislation are still in progress. Property tax reform is based on regulating housing price, adjusting the gap between the rich and the poor, promoting tax revenue, and achieving fairness and efficiency is a process that requires comprehensive coordination among all aspects. Reform must be in the land resources management and urban real estate management department and other relevant departments cooperate with linkage under gradual power (Zhong, 2008), analyzes the status quo of the problems and difficulties encountered, and summarizes the pilot reform of the deficiencies and reasons. And then we should further improve the system of land management, real estate registration and management system, related local property tax system of detailed rules for the implementation of provisions, to solve the problems existing in the present, to further promote the reform of property tax in China. This article is based on researching and sorting out various difficulties in the process of further real estate tax reform. However, it lacks detailed measures to improve the existing problems and the lack of perfection, the author will promote the reform of real estate tax research in the future to improve measures and methods for further research and discussion.

\section{Conflicts of Interest}

The author declares no conflicts of interest regarding the publication of this paper.

\section{References}

Bureau of Statistics of the People's Republic of China (2010). China Statistical Yearbook. Beijing: China Statistics Press.

Bureau of Statistics of the People's Republic of China (2019). China Statistical Yearbook. Beijing: China Statistics Press. 
China Real Estate Association (2018). Chengdu Housing Prices. 2018-01-04.

China Real Estate Association (2019). Chengdu Housing Prices. 2019-01-12.

Hou, B. N. (2017) The Discussion on the Predicament and Approach of the Reform of Real Estate Tax in China. China Management Informatization, 20, 103-104.

Jiang, Y. (2017). The Target Orientation and Path Choice of China's Real Estate Tax Reform. The Chinese and Foreign Entrepreneurs, No. 20, 86-87.

Lan, Z. Q. (2013). The Research on tax Division between Central and Local Governments in China. Shanxi: Shanxi University of Finance and Economics.

Zhang, X. Y. (2015). The Research on the Present Situation and Reform of China's Real Estate Tax System. Beijing: NCEPU.

Zhong, D. N. (2008). Fairness and Efficiency: A Study on the Functional Orientation and Tax Category Setting reform of China's Real estate Tax system. Reform and Strategy, 2008, 16-19. 